\title{
A study on the antecedents of supplier commitment in support of logistics operations
}

\author{
Christina W.Y. Wong* \\ Business Division, Institute of Textiles and Clothing, \\ The Hong Kong Polytechnic University, \\ Hung Hom, Kowloon, Hong Kong \\ E-mail: tcchris@inet.polyu.edu.hk \\ *Corresponding author
}

\section{Kee-hung Lai, Y.H. Venus Lun and T.C.E. Cheng}

Department of Logistics and Maritime Studies,

The Hong Kong Polytechnic University,

Hung Hom, Kowloon, Hong Kong

E-mail: lgtmlai@inet.polyu.edu.hk

E-mail: lgtvlun@inet.polyu.edu.hk

E-mail: lgtcheng@inet.polyu.edu.hk

\begin{abstract}
Supplier inputs need to be delivered at the right time in the right quality and quantity to fully satisfy the operations requirements of buying firms. In achieving these performance goals, the importance of supplier commitment in managing the buyer-supplier relationship (BSR) should not be neglected in logistics operations. Due to organisational differences on operations priorities, it is a challenging task to manage a BSR which is inherently complex with many transactional and institutional aspects involved. This challenge is salient in logistics management with multiple upstream and downstream parties involved where the lack of concerted efforts can compromise performance of the entire logistics chain. For many enterprises, it remains unclear on how to nurture supplier commitment in support of their logistics operations. Considering this research void, we examine the antecedents of supplier commitment covering both transactional and institutional factors influencing supplier commitment in the BSR. Survey data collected from 358 suppliers of an international buying firm indicate that business uncertainty discourages supplier commitment, but the commitment can be reinforced with both explicit and implicit contracts used for governing the BSR.
\end{abstract}

Keywords: supplier commitment; uncertainty; buyer-supplier relationship; contract.

Reference to this paper should be made as follows: Wong, C.W.Y., Lai, K-h., Lun, Y.H.V. and Cheng, T.C.E. (2012) 'A study on the antecedents of supplier commitment in support of logistics operations', Int. J. Shipping and Transport Logistics, Vol. 4, No. 1, pp.5-16. 
Biographical notes: Christina W.Y. Wong is currently an Assistant Professor at the Business Division of Institute of Textiles and Clothing, The Hong Kong Polytechnic University. Her recent work has appeared in Transport Reviews, Journal of Operations Management, Omega, International of Production Economics, amongst other journals.

Kee-hung Lai is an Associate Professor at the Department of Logistics and Maritime Studies, The Hong Kong Polytechnic University. His research interests are in the area of shipping and logistics management. $\mathrm{He}$ has co-authored three books and over 70 papers in journals such as Journal of Business Logistics, Transportation, Transportation Research Part E, and others.

Y.H. Venus Lun is a Lecturer at the Department of Logistics and Maritime Studies, The Hong Kong Polytechnic University. Her research interest is in the area of shipping operations and management. She has authored five books published by international publishers. Her research papers appear in such scholarly journals as Expert Systems with Application, International Journal of Production Economics, International Journal of Production Research, International Journal of Shipping and Transport Logistics, Resources, Conservation and Recycling, Transport Reviews, Transportation Journal and others.

T.C.E. Cheng is the Chair Professor of Management at the Department of Logistics and Maritime Studies of The Hong Kong Polytechnic University. He obtained his $\mathrm{PhD}$ and $\mathrm{ScD}$ from the University of Cambridge, UK. He has previously taught in Canada, England, and Singapore. His research interests are in operations management. He has published over 500 papers in such journals as California Management Review, Management Science, MIS Quarterly, Operations Research, and Organization Science, and co-authored ten books. He regularly advises business, industry, and government, and provides management training and executive development to public and private organisations.

\section{Introduction}

While firms rely heavily on logistics service to conduct global trade, shipping activities in a logistics chain are a key element of economic development as they facilitate industrial specialisation and scale economy in production, leading to lower product prices and higher product availability to service international trade (Lun and Marlow, 2011; Lun et al., 2011). The advent of containerisation has profoundly changed the pattern of international transport. Since the introduction of container boxes for handling cargo movements internationally, containerised trade has undergone significant growth development. Such a development is related to the container terminals which are nodes that link various transport modes to facilitate flows of goods along the production to consumption ends of a supply chain. Under an increasingly globalised market, managing the buyer-supplier relationship (BSR) amongst container terminals and shippers has been an important part of logistics management and business performance (Lai, 2009). In this regard, supplier commitment characterised with investment in resources and flexibility by suppliers to fulfil the needs of container terminals as buyer firms is increasingly emphasised in logistics operations (Wong et al., 2009b; Yang et al., 2008). Such 
commitment is related to the willingness of suppliers to sacrifice their short-term gains in pursuit of long-term benefits from the BSR (Anderson and Weitz, 1992; Dwyer et al., 1987; Jap and Ganesan, 2000; Lai et al., 2008). Failing to establish supplier commitment, a buyer firm can suffer from shortage of continuous and reliable inputs ranging from office supplies and equipment, to facility maintenance and repair services in support of their operations. As an organisational resource, a committed supplier is willing to resist short-term alternatives, make investments, and allocate resources to satisfy the requirements of buyer firms. Another benefit of supplier commitment relates to enhanced exchange efficiency for a BSR due to the reduced time and cost of buyer firms to hedge and monitor supplier performance. With committed suppliers, buyer firms can ensure quality supply and timely access to the needed resource inputs in operations (Lai et al., 2005; Yang et al., 2009).

There are knowledge gaps on supplier commitment on two logistics research fronts. First, understanding on the determinants of supplier commitment in support of logistics operations is sparse. Although exchange arrangements such as transactional and institutional relations are essential for managing a BSR (Lai et al., 2005), there is no clue as to which governance approach is more effective in cultivating supplier commitment. Second, the increasing globalisation of business require container terminals as buyer firms to purchase from their suppliers varying in operations priorities and cultural backgrounds (Marble and Lu, 2007).

We draw on the transaction cost economics (TCE) and the institutional theory (INT) to build and empirically test an integrated theoretical framework in a logistics management context with data collected from the supplier population of a global container terminal operator. The results advance our understanding on whether and how transactional and institutional factors of BSR affect supplier commitment for the logistics operations of the container terminal operator as the buyer firm.

\section{Theoretical background and hypotheses development}

Containerisation has revolutionised the way in which firms transport their goods around the world. Being a vital part of a transport infrastructure, container terminals provide facilities for berthing ships, and deploying quay cranes to manage cargo transfer from ships to ships, or ships to shores and vice versa (Lun et al., 2010; Lun and Carious, 2009). A container terminal can also be classified as a multimodal node where ocean ships, short-sea barges, and road and rail modes converge, while linking between waterborne and land transport. Container terminals play a critical role in a supply chain by taking responsive actions in supporting goods movements to service customer demands (Cheng et al., 2010). In addition to the basic operations of cargoes handling and storage, terminal operators nowadays need to create value by providing services such as cargo consolidation activities to facilitate multimodal transport. Container terminals operate under bidirectional logistics systems, where cargos from and to ship or inland transport are both handled at the ports. Such bidirectional logistics systems make container terminators' operations far more complex than the simple loading and discharging operations.

Container terminals have evolved from a cargo handling point to a distribution centre with physical infrastructure servicing as logistics hubs in container transport chains. 
Container ports and their related commercial activities not only act as places facilitating trade, but also attract investment in commercial infrastructure such as trading and financial institutions. According to TCE, there are costs incurred for conducting economic transactions and governing the exchange (Williamson, 1975). This theory suggests that exchange in a BSR is inefficient particularly under an uncertain business environment where the opportunistic behaviours of the involved parties are difficult to control (Williamson, 1985). In the context of terminal operations, transactional arrangements (e.g., explicit contract with vendors) and transaction specific investment (e.g., terminal management system to support effective communication with vendors) are employed to facilitate economic exchange in a BSR. However, this TCE perspective has been criticised for neglecting the institutional aspects in exchange relationship (e.g., implicit contract and exchange norms) with respect to legitimacy for social and economic rewards (DiMaggio and Powell, 1983; Meyer and Rowan, 1977). These institutional aspects are embedded in economic exchanges, shaping the behaviour and attitude of trading partners towards future transactions due to their mutual understanding and social consensus (Lai et al., 2006). Institutional arrangement is instrumental for developing collaboration and commitment between partner firms and hence establishing long-term partnership (Dwyer and Oh, 1988). As such, a BSR is dependent not only on economic factors, but also institutional arrangements transcending formal contracts that entrust both parties with mutually agreeable outcomes.

According to TCE, business uncertainty limits organisational ability to predict the outcomes of their actions and future events in managing a BSR (Hooper, 2008). Suppliers presented with business uncertainty will have difficulty in predicting the demand and order requirements of their buyer firms (Kohli, 1989; Lai et al., 2008). For instance, terminal operators may change their purchasing policy to meet their environmental protection objectives by demanding the use of environmentally friendly materials and disposal of hazardous substances in a responsible manner. This business uncertainty inherent in a BSR restrains the commitment of suppliers to dedicate resources for satisfying the requirements of their buyer firms, as the former are unsure of a long-term exchange relationship (Morgan and Hunt, 1994) and their investment return in the BSR. Thus, when suppliers perceive business uncertainty in a BSR, their commitment can be weakened due to uncertain returns on their investment made and resources allocated in the relationship.

Hypothesis 1 The business uncertainty as perceived by suppliers in a BSR will weaken their commitment in the relationship.

Explicit contract involves detailed transactional arrangement that specifies the roles and obligations of the exchange parties for specific performance and actions (Cannon et al., 2000). An explicit contract governs a BSR by specifying rules and agreements as well as reducing uncertainty in behaviours and performance expectations of the involved parties. Such transactional arrangement enables partners to develop customised approaches and agreements (Williamson, 1991), where an individual party failing to perform according to the contract specifications is subject to penalty. For instance, terminal operators aim to reduce sulphur dioxide emission by switching rubber-tyred gantry cranes (RTGSs) fuelled by industrial diesel oil to ultralow sulphur diesel oil. The fuel suppliers who fail to comply with such requirement as stated in the contract may be penalised or would be requested to terminate the contractual relationship. While disputes in a BSR can be handled amicably and equitably under this transactional arrangement, explicit contract 
also reduces the risks of non-conformance and develops trust between exchange partners. This transactional arrangement will build confidence in suppliers that the BSR is long-term and mutually beneficial, motivating their investment and resources allocation in facilitating the operations of their buyer firms.

Hypothesis 2 The use of explicit contract in a BSR will enhance supplier commitment in the relationship.

Although explicit contract specifies detailed expectations and obligations of partner firms in the BSR, it is costly and infeasible to take account of all contingencies or modify the transactional agreements (Rindfleisch and Heide, 1997). Such limitation of explicit contract can be overcome with the complement by implicit contract emphasising the legitimate actions of exchange partners. For instance, terminal operators may voluntarily participate to reduce their adverse environmental impact to meet the reduction of sulphur dioxide emission, which is one of the root causes of acid rain and smog, following the guideline of Hong Kong's Clean Air Charter. Such engagement of the terminal operators imposes implicit contract to their suppliers in being environmentally responsible in delivery of their physical supplies and services to reduce sulphur dioxide emission. Implicit contract guides mutual understanding and expectations of partner firms on their roles and responsibilities in a BSR. Such institutional arrangement is helpful for developing a trusting relationship (Anderson and Weitz, 1989), while strengthening cooperation between the involved parties. In a BSR characterised with implicit contract to reinforce mutual expectations, suppliers are more likely to expect fairness and equity in the BSR, motivating their commitment to pursue a mutually beneficial exchange relationship.

Hypothesis 3 The use of implicit contract in a BSR will strengthen supplier commitment in the relationship.

\section{Research methodology}

To test the hypotheses, we focused on the exchange relationship involving a global container terminal with its population of suppliers to minimise the potentially confounding effects of differences in exchange arrangements between different dyadic relationships. Studying this container terminal is appropriate due to its globalised operations involving suppliers from different cultural and contextual backgrounds (Wong et al., 2009c).

The key informant approach was used to collect data from the population of 1,348 suppliers from the container terminal operator (Phillips and Bagozzi, 1986). The informants selected were the executives who are responsible for handling the supply relationships with the container terminal operator. These suppliers are requested, with support from the container terminal operator, to report their BSR with the latter.

\section{Measurement development}

A measurement instrument in the form of a survey questionnaire was developed on the basis of an extensive literature review. The theoretical constructs of this study were 
evaluated using multi-item scales based on Churchill's (1979) suggested guidelines. We developed five questionnaire items to measure explicit contract based on Cannon et al. (2000) and another five items to measure implicit contract based on Lusch and Brown (1996). The measurement scale of business uncertainty was adopted from Heide and John (1990). With reference to Siguaw et al. (1998), we developed five measurement items for evaluating supplier commitment.

The questionnaire was refined based on feedback from a panel discussion with purchasing and supply academics and practitioners. A pilot test was conducted on the survey questionnaire with a convenient sample of 30 suppliers servicing the container terminal operator. Results and feedback after testing the survey instrument indicated that the measurement scales are valid and reliable. The final measurement items are summarised in Appendix.

After two mailings, 365 completed questionnaires were received with a response rate of $27 \%$. Five responses were excluded due to excessive missing data in their completed survey and another two were discarded due to inadequate informant's knowledge about the BSR being studied, resulting in 358 qualified responses for data analyses. To ensure the informants possess sufficient knowledge and are involved in the BSR with the container terminal operator, we asked three questions to assess the quality of the informants: "the knowledge you have about the supply relationship of your company with the container terminal operator," "the knowledge you have about the requirements of the container terminal operator for the items supplied by your company," "your involvement in the supply relationship of your company with the terminal operator is" on a five-point Likert scale of $1=$ extremely low and $5=$ extremely high. The respondents who had answered with a four or five to at least one of these three questions were considered qualified to answer the questionnaire. As a result of this test, two completed survey questionnaires were excluded.

\section{$5 \quad$ Validity and reliability}

We performed confirmatory factor analysis to validate the measurement scales. The standardised factor loadings range from 0.55 to 0.96 , and are statistically significant at $p>0.01$. These results suggest that the theoretical constructs possess convergent validity. The overall goodness-of-fit indices support the four-factor measurement model with $\chi^{2}=348.41, d f=129, p<.001, \mathrm{CFI}=0.95$, RMSEA $=0.06$, and TLI $=0.94$, where these indices exceeding the recommended thresholds suggest acceptance of the model. The Cronbach alpha internal consistency reliability estimates were also above the recommended threshold of 0.70 (Nunnally, 1984) in the range of 0.86 to 0.92 . The results suggest the scales are sufficiently reliable. The average variance extracted (AVE) of each theoretical construct exceed the recommended threshold value of 0.50 (Fornell and Larcker, 1981), while the composite reliability (CR) of each construct exceeded the threshold of 0.60 . These findings provide evidence of discriminant validity of these measurement scales. 


\section{Structural model testing}

The hypothesised model was tested with structural equation model using AMOS 17.0. The constructs on business uncertainty, explicit contract, and implicit contract were modelled as exogenous variables, while supplier commitment was operated as an endogenous variable. The test results offer support for our hypothesised relationships. The estimation results indicate that the model provides reasonable fit to the data with the following indices: $\chi^{2}=348.41, d f=129, p<.001, \mathrm{CFI}=0.95$, RMSEA $=0.06$, and TLI $=0.94$.

We predict that economic exchange factors in terms of business uncertainty and explicit contract are negatively and positively related to supplier commitment, respectively. We find that the business uncertainty $\rightarrow$ supplier commitment path was negatively significant $(\beta=0.25 ; p<0.001)$, supporting Hypothesis 1 . The explicit contract $\rightarrow$ supplier commitment path was positively significant $(\beta=0.21 ; p<0.01)$, supporting Hypothesis 2. Our prediction regarding implicit contract as antecedents of supplier commitment also receives support. The results suggest that implicit contract is positively related to supplier commitment $(\beta=0.18 ; p<0.01)$.

\section{Implications}

This study sheds light on the importance of establishing both transactional as well as institutional mechanisms to nurture supplier commitment in support of logistics operations in a BSR. Recognising the value of supplier commitment as a critical success factor in a BSR, we hypothesise that business uncertainty as perceived by suppliers in predicting the demand and future exchange with the buyer firm is detrimental to their commitment to the BSR. The result confirms our argument that the business uncertainties perceived by suppliers in a BSR will restrain their investment and allocation of resources in the relationship. Suppliers are less willing to make long-term investment, maintain flexibility, and provide resources to accommodate the needs of terminal operators as buyer firms if business uncertainties exist in the BSR. This finding offers managerial implications to buyer firms seeking to nurture supplier commitment in their BSR, particularly for container terminal operators to ensure supplies for their operations in support for international trade. Improving the transparency of information related to their sales volume, demand requirements, order size, and order cycle can be helpful for reducing the business uncertainty encountered by suppliers and hence enticing them to the BSR (Wong et al., 2009a).

Both economic and institutional arrangements, in terms of explicit and implicit contracts, are important for buyer firms to cultivate supplier commitment. This finding is consistent with previous studies (e.g., Morgan and Hunt, 1994) that implicit contract reinforces mutual understanding and expectations of partner firms, nurturing a long-term oriented BSR. On the other hand, explicit contract safeguards the exchange by detailing the specifications and requirements of economic transactions. The use of explicit contract can curb opportunistic behaviours in a BSR, enhancing the confidence of suppliers to invest in the relationship. Although prior studies have criticised the value of explicit contract due to its lack of flexibility to take account of contingencies (Macaulay, 1963), explicit contract is still necessary to safeguard liability if a BSR fails to last subsequently. 
The imposition of both explicit and implicit contractual agreements by container terminal operators can improve commitment of their suppliers in complying with their changing operations requirements, which are introduced by the ever changing global trade environment.

\section{Limitations and future research}

The interpretation of the study findings is subject to several limitations and we leave them for investigation by future research. First, cross-sectional research design was employed, where a snapshot of the BSR is captured. The dynamic evolution of the relationships was not taken into account in our data collection and analyses. Future research may consider conducting a longitudinal research of the BSR to determine if the changes of the economic and institutional arrangements may affect supplier commitment.

This research was designed to survey the supplier population of the container terminal operator. Such design is useful for controlling externalities and extraneous variables of the BSR under study, but the generalisability of the study findings is compromised. Future research may replicate this study across a collection of buyer firms and their respective suppliers to improve the generalisability of findings, and test the robustness of the transactional and institutional arrangements to engender supplier commitment in supporting the logistics management of buyer firms.

\section{Acknowledgements}

We would like to thank two anonymous reviewers for their useful comments on earlier versions of this paper. This research is supported in part by the Research Grants Council of the Hong Kong Special Administration Region (GRF PolyU 5301/08E).

\section{References}

Anderson, E. and Weitz, B. (1989) 'Determinants of continuity in conventional industrial channel dyads', Marketing Science, Vol. 8, No. 4, pp.310-323.

Anderson, E. and Weitz, B. (1992) 'The use of pledges to build and sustain commitment in distribution channels', Journal of Marketing Research, Vol. 29, No. 1, pp.18-34.

Cannon, J.P., Achrol, R.S. and Gundlach, G.T. (2000) 'Contracts, norms, and plural form governance', Journal of Academy of Marketing Science, Vol. 28, No. 2, pp.180-194.

Cheng, J.K., Tahar, R.M. and Ang, C-L. (2010) 'Understanding the complexity of container terminal operation through the development of system dynamics model', International Journal of Shipping and Transport Logistics, Vol. 2, No. 4, pp.429-443.

Churchill, G.A.J. (1979) 'A paradigm for developing better measures of marketing constructs', Journal of Marketing Research, Vol. 16, No. 1, pp.64-73.

DiMaggio, P.J. and Powell, W.W. (1983) 'The iron cage revisited: institutional isomorphism and collective rationality in organizational fields', American Sociological Review, Vol. 48, No. 2, pp.147-160.

Dwyer, F.R. and Oh, S. (1988) 'A transaction cost perspective on vertical contractual structure and interchannel competitive strategies', Journal of Marketing, Vol. 52, No. 2, pp.21-34. 
Dwyer, R.R., Schurr, P.H. and Oh, S. (1987) 'Developing buyer-seller relations', Journal of Marketing, Vol. 51, No. 2, pp.11-28.

Fornell, C. and Larcker, D.F. (1981) 'Evaluating structural equation models with unobserved variables and measurement errors', Journal of Marketing Research, Vol. 18, No. 1, pp.39-50.

Heide, J.B. and John, G. (1990) 'Alliances in industrial purchasing: the determinants of joint action in buyer-supplier relationships', Journal of Marketing Research, Vol. 27, No. 10, pp.24-36.

Hooper, L. (2008) 'Paying for performance: uncertainty, asymmetric information and the payment model', Research in Transportation Economics, Vol. 22, No. 1, pp.157-163.

Jap, S.D. and Ganesan, S. (2000) 'Control mechanisms and the relationship life cycle: implications for safeguarding specific investments and developing commitment', Journal of Marketing Research, Vol. 37, No. 2, pp.227-245.

Kohli, A. (1989) 'Determinants of influence in organizational buying: a contingency approach', Journal of Marketing, Vol. 53, No. 3, pp.50-65.

Lai, K-H. (2009) 'Linking exchange governance with supplier cooperation and commitment: a case of container terminal operations', Journal of Business Logistics, Vol. 30, No. 1, pp.243-263.

Lai, K-H., Bao, Y. and Li, X. (2008) 'Channel relationship and business uncertainty: evidence from the Hong Kong market', Industrial Marketing Management, Vol. 37, No. 6, pp.713-724.

Lai, K-H., Cheng, T.C.E. and Yeung, A.C.L. (2005) 'Relationship stability and supplier commitment to quality', International Journal of Production Economics, Vol. 96, No. 3, pp.397-410.

Lai, K-H., Wong, C.W.Y. and Cheng, T.C.E. (2006) 'Institutional isomorphism and the adoption of information technology for supply chain management', Computers in Industry, Vol. 57, No. 1, pp.93-98.

Lun, V.Y.H. and Marlow, P. (2011) 'The impact of capacity on firm performance: a study of the liner shipping industry', International Journal of Shipping and Transport Logistics, Vol. 3, No. 1, pp.57-71.

Lun, V.Y.H., Pang, K.W. and Panayides, P.M. (2010) 'Organizational growth and firm performance in the international container shipping industry', International Journal of Shipping and Transport Logistics, Vol. 2, No. 2, pp.206-223.

Lun, Y.H.V. and Carious, P. (2009) 'An analytical framework for managing container terminals', International Journal of Shipping and Transport Logistics, Vol. 1, No. 4, pp.419-436.

Lun, Y.H.V., Lai, K.H., Wong, C.W.Y., Ng, C.T. and Cheng, T.C.E. (2011) 'Research in shipping and transport logistics', International Journal of Shipping and Transport Logistics, Vol. 3, No. 1, pp.1-5.

Lusch, R.F. and Brown, J.R. (1996) 'Interdependency, contracting, and relational behavior in marketing channels', Journal of Marketing, Vol. 60, No. 4, pp.19-38.

Macaulay, S. (1963) 'Non-contractual relations in business: a preliminary study', American Sociological Review, Vol. 28, No. 1, pp.55-67.

Marble, R.P. and Lu, Y. (2007) 'Culturalizing enterprise software for the Chinese context: an argument for accommodating guanxi-based business practices', International Journal of Production Economics, Vol. 107, No. 2, pp.364-379.

Meyer, J.W. and Rowan, B. (1977) 'Institutional organizations: formal structure as myth and ceremony', American Journal of Sociology, Vol. 83, No. 2, pp.340-363.

Morgan, R.M. and Hunt, S.D. (1994) 'The commitment-trust theory of relationship marketing', Journal of Marketing, Vol. 58, No. 3, pp.20-38.

Nunnally, J. (1984) Psychometric Theory, McGraw-Hill, New York.

Phillips, L.W. and Bagozzi, R.P. (1986) On Measuring the Organizational Properties of Distribution Channels: Methodological Issues in the Use of Key Informants, JAI Press, Greenwich, CT.

Rindfleisch, A. and Heide, J.B. (1997) 'Transaction cost analysis: past, present, and future applications', Journal of Marketing, Vol. 61, No. 4, pp.30-54. 
Siguaw, J.A., Simpson, P.M. and Baker, T.L. (1998) 'Effects of supplier market orientation on distributor market orientation and the channel relationship: the distributor perspective', Journal of Marketing, Vol. 62, No. 2, pp.99-111.

Williamson, O.E. (1975) Markets and Hierarchies: Analysis and Antitrust Implications, The Free Press, New York.

Williamson, O.E. (1985) The Economic Institutions of Capitalism, Free Press, New York.

Williamson, O.E. (1991) 'Comparative economic organization: the analysis of discrete structural alternatives', Administrative Science Quarterly, Vol. 36, No. 2, pp.269-296.

Wong, C.W.Y., Lai, K-H. and Cheng, T.C.E. (2009a) 'Complementarities and alignment of information systems management and supply chain management', International Journal of Shipping and Transport Logistics, Vol. 1, No. 2, pp.156-171.

Wong, C.W.Y., Lai, K-H. and Ngai, E.W.T. (2009b) 'The role of supplier operational adaptation on the performance of IT-enabled transport logistics under environmental uncertainty', International Journal of Production Economics, Vol. 122, No. 1, pp.47-55.

Wong, C.W.Y., Lai, K-H. and Teo, T.S.H. (2009c) 'Institutional pressures and mindful information technology management: the case of a container terminal in China', Information \& Management, Vol. 46, No. 8, pp.434-441.

Yang, C.C., Marlow, P.B. and Lu, C.S. (2009) 'Assessing resources, logistics service capabilities, innovation capabilities and performance of container shipping services in Taiwan', International Journal of Production Economics, Vol. 122, No. 1, pp.4-20.

Yang, J., Wang, J., Wong, C.W.Y. and Lai, K-H. (2008) 'Relational stability and alliance performance in supply chain', Omega, Vol. 36, No. 4, pp.600-608. 


\section{Appendix}

Survey instrument

\begin{tabular}{|c|c|c|}
\hline Constructs & Measurement items & $\begin{array}{l}\text { Standardised } \\
\text { factor loadings }\end{array}$ \\
\hline \multicolumn{3}{|c|}{$\begin{array}{l}\text { Explicit contract } \\
\alpha=.90 ; \mathrm{CR}=.90 ; \mathrm{AVE}=.60 \\
(1=\text { strongly disagree to } \\
5=\text { strongly agree })\end{array}$} \\
\hline 1 & $\begin{array}{l}\text { The specific investment we made is clearly } \\
\text { specified in our contract with the container } \\
\text { terminal operator. }\end{array}$ & .62 \\
\hline 2 & $\begin{array}{l}\text { The duration of the contract is clearly specified } \\
\text { in our contract with the container terminal } \\
\text { operator. }\end{array}$ & .86 \\
\hline 3 & $\begin{array}{l}\text { The technical know-how of our firm is clearly } \\
\text { specified in our contract with the container } \\
\text { terminal operator. }\end{array}$ & .82 \\
\hline 4 & $\begin{array}{l}\text { The termination conditions are clearly } \\
\text { specified in our contract with the container } \\
\text { terminal operator. }\end{array}$ & .90 \\
\hline 5 & $\begin{array}{l}\text { The disputes and arbitration concerning the } \\
\text { products and services we supply are clearly } \\
\text { specified in our contract with the container } \\
\text { terminal operator. }\end{array}$ & .90 \\
\hline \multicolumn{3}{|c|}{$\begin{array}{l}\text { Implicit contract } \\
\alpha=.92 ; \mathrm{CR}=.92 ; \mathrm{AVE}=.75 \\
(1=\text { strongly disagree to } \\
5=\text { strongly agree })\end{array}$} \\
\hline 1 & $\begin{array}{l}\text { In dealing with the container terminal operator, } \\
\text { we and the terminal operator have a mutual } \\
\text { understanding of how remedies for failure will } \\
\text { be performed }\end{array}$ & .96 \\
\hline 2 & $\begin{array}{l}\text { In dealing with the container terminal operator, } \\
\text { we and the container terminal operator have a } \\
\text { mutual understanding of the responsibilities of } \\
\text { each party. }\end{array}$ & .83 \\
\hline 3 & $\begin{array}{l}\text { In dealing with the container terminal operator, } \\
\text { we and the container terminal operator have a } \\
\text { mutual understanding of what will happen in } \\
\text { events occurring that were not planned. }\end{array}$ & .94 \\
\hline 4 & $\begin{array}{l}\text { In dealing with the container terminal operator, } \\
\text { we and the container terminal operator have a } \\
\text { mutual understanding of how agreements will } \\
\text { be handled or resolved. }\end{array}$ & .70 \\
\hline
\end{tabular}




\section{Survey instrument (continued)}

\begin{tabular}{|c|c|c|}
\hline Constructs & Measurement items & $\begin{array}{c}\text { Standardised } \\
\text { factor loadings }\end{array}$ \\
\hline \multicolumn{3}{|c|}{$\begin{array}{l}\text { Business uncertainty } \\
\alpha=.89 ; \mathrm{CR}=.89 ; \mathrm{AVE}=.67 \\
(1=\text { extremely difficult to } \\
5=\text { extremely easy })\end{array}$} \\
\hline 1 & $\begin{array}{l}\text { Forecasting our sales volume to the container } \\
\text { terminal operator is }\end{array}$ & .76 \\
\hline 2 & $\begin{array}{l}\text { Forecasting the container terminal operator's } \\
\text { demand requirements for the items we supply } \\
\text { is }\end{array}$ & .76 \\
\hline 3 & $\begin{array}{l}\text { Forecasting the container terminal operator's } \\
\text { order size is }\end{array}$ & .89 \\
\hline 4 & $\begin{array}{l}\text { Forecasting the container terminal operator's } \\
\text { order cycle is }\end{array}$ & .86 \\
\hline \multicolumn{3}{|c|}{$\begin{array}{l}\text { Supplier commitment } \\
\alpha=.86 ; \mathrm{CR}=.87 ; \mathrm{AVE}=.57 \\
(1=\text { strongly disagree to } \\
5=\text { strongly agree })\end{array}$} \\
\hline 1 & $\begin{array}{l}\text { We defend the container terminal operator } \\
\text { when outsiders criticise the terminal operator. }\end{array}$ & .71 \\
\hline 2 & $\begin{array}{l}\text { We would not drop the container terminal } \\
\text { operator even if another customer offers us } \\
\text { better terms. }\end{array}$ & .55 \\
\hline 3 & $\begin{array}{l}\text { We are willing to dedicate whatever people } \\
\text { and resources it takes to make the container } \\
\text { terminal operator a satisfied customer. }\end{array}$ & .82 \\
\hline 4 & $\begin{array}{l}\text { We are willing to make a long-term investment } \\
\text { in helping the container terminal operator. }\end{array}$ & .87 \\
\hline 5 & $\begin{array}{l}\text { We have a strong sense of loyalty to the } \\
\text { container terminal operator. }\end{array}$ & .78 \\
\hline
\end{tabular}

